\title{
Impact of Nitrogen and Phosphorus efficiency on the growth and flowering of Helichrysum bractum
}

\author{
Maryam I.S.Alkurdi \\ (Slovak University of Agriculture in Nitra, Faculty of Horticulture and Landscape Engineering, Department of \\ Garden and Landscape Architecture, Tulipanova street No.7, 94901 Nitra, Slovak Republic)
}

\begin{abstract}
The study was conducted in the Akam plantation at Erbil city, University of Salahaddin Erbil - Iraq, during growing season of 2009-2010 from October - May. Plants of Helichrysum bracteatum were planted in plastic pots 20. The experiment was conducted in Randomized Complete Design (RCD) in three replication and nine treatments and the data were in analyzed with the general linear model procedures in SAS, and Duncan test at level 0.05 was used for comparing the means, tow type of fertilizer used in this experiment, Urea fertilizer available Nitrogen is (46\% N) and triple super phosphate available phosphate (p2o5) 45\%, in different levels $(0,0.5,1 \mathrm{mg} /$ pot $)$. Fertilizers were applied after 45 days from planting of the plants. The results showed that plant height increased significantly with increasing nitrogen up to $1 \mathrm{mg} / \mathrm{pot}$. The highest number of flowers obtained from $1 \mathrm{mg} /$ pot Phosphate and the difference was significantly comparing with other treatments. The study concluded that $0.5 \mathrm{mg}$ Nitrogen/ pot is adequate for maximum fresh and dry weight of plants.
\end{abstract}

Keywords: Helichrysum bracteatum, morphological characteristics, Nitrogen, Phosphorus

\section{Introduction}

Helichrysum bracteatum commonly known as the strawflower is a flowering plant in the family Asteraceae native to Australia, with yellow, orange, pink, deep rose, red, wine, magneto, purple and white blooms. It was known as Helichrysum bracteatum for many years before being transferred to a new genus Xerochrysum in 1990. Helichrysum are producing worldwide as fresh and dried flowers [1]; [2]; [3]. It was introduced to Europe around 1800. Xerochrysum have been commonly used in folk medicine as an herbal tea. They are known for their anti inflammatory [4]. Helichrysum bracteatum was one of several species that became popular with European royalty and nobility from the early 19th century.

To achieve the best possible quality of yield favourable conditions are required for plant growth and these conditions require the soil to have an adequate and well- balanced supply of nutrition elements. Nitrogen is one of the most important nutritional elements for plants and is essential for all biological processes that occur in plant and primary life. Plant growth is not possible without nitrogen and in conditions of low levels of nitrogen plants remain small. Only legumes are able to use nitrogen from the atmosphere. The reaction of phosphorus in the soil is complex and determined by the volubility of phosphorus, when there is a low amount in the soil it with ions such as calcium, magnesium, iron, aluminium and zinc. [5] Summarized the role of NPK on physiology of plants. Nitrogen is a component of amino acid, which is essential for protein synthesis. Nitrogen bases like pyrimidines and purines and many co-enzymes need nitrogen for their synthesis. It is also a component of cytochrome and chlorophyll which are essential for photosynthesis. While Phosphorus forms a source of energy in the form of ATP and ADP, the cell division is also influenced by phosphorus. It is also a component of many enzymes, co-enzymes, nucleic acids and phospholipids and potash acts as catalyst for various enzymes and co-enzymes and starch synthesis takes place in the presence of potash. It has a vital role in photo respiration, translocation of metabolites and transpiration.

[6] observed increased plant height in China aster with the application of nitrogen up to $180 \mathrm{~kg}$ and phosphorus $120 \mathrm{~kg} / \mathrm{ha}$. Similarly, [7] obtained maximum plant height with 120:60:60 kg NPK / ha. While [8] recorded maximum plant height with 100:60:60 kg NPK /ha. Whereas, significantly maximum plant height was recorded at 250:120:75 kg NPK / ha [9], and at 200:100:50 kg NPK / ha by [10] in China aster.

[11] in marigold indicated that, application of nitrogen and phosphorus each at $40 \mathrm{~g}$ per square metre recorded higher plant height $(128.8 \mathrm{~cm})$ and maximum number of branches per plant (4.05). [12] reported in cosmos, that among the nutrient elements nitrogen and phosphorus deficiency showed maximum reduction in growth. Maximum growth of plants was obtained with combined application of $20 \mathrm{~g}$ nitrogen, $10 \mathrm{~g}$ phosphorus and $10 \mathrm{~g}$ potash $/ \mathrm{m}^{2}$. [13] obtained significantly maximum plant height $(69.6 \mathrm{~cm})$ and number of branches (21.9) with application of $200 \mathrm{~kg} \mathrm{~N} /$ ha., compared to control (52.5 $\mathrm{cm}$ and 12.8 respectively) in marigold. Significantly higher flower yield (35786.92 kg/ha) was recorded with the application of higher nitrogen level $(150 \mathrm{~kg} / \mathrm{ha})$ in annual Chrysanthemum [14]. While [15] noticed in marigold that the days required for flowering was prolonged from 68.03 days in (control) to 71.29 days with application of nitrogen $\left(30 \mathrm{~g} / \mathrm{m}^{2}\right)$. Further, more number of flowers and highest yield of flower was obtained with $30 \mathrm{~g} \mathrm{~N} / \mathrm{m}^{2}$. [16] reported in African marigold 
that application of $200 \mathrm{~kg}$ of $\mathrm{N}$ and $\mathrm{P}$. fertilizers / ha recorded increased diameter of flower, number of flowers per plant and flower yield /plant and / ha., when compared to other levels of $\mathrm{N}$ and $\mathrm{P}$.

The main aims of this study determine correlative relationship between NP application and Helichrysum bracteatum morphological characteristics and to work out the economics of integrated nutrient management in Helichrysum bracteatum.

\section{Material And Methods}

The field experiment was conducted in the Akam plantation at Erbil city, University of Salahaddin Erbil - Iraq, during growing season of 2009- 2010 from October - May. Plants of Helichrysum bracteatum were planted in a plastic pots $20 \mathrm{~cm}$ in diameter filled with Soil substrates (River sand) or loamy soil. An experiment was laid out as factorial Randomized Complete Design (RCD) in three replication and nine treatments. The data were analyzed with the general linear model procedures in SAS, and Duncan test at level 0.05 was used for the means separation. Tow type of fertilizer used in this experiment, Urea fertilizer available Nitrogen is $46 \%$ and triple super phosphate available phosphate (p2o5) 45\%, in different levels $(0,0.5,1 \mathrm{mg} / \mathrm{pot}) \quad(\mathrm{N} 0=0$, $\mathrm{N} 1=0.5, \mathrm{~N} 2=1),(\mathrm{P} 0=0, \mathrm{P} 1=0.5, \mathrm{P} 2=1)$. Fertilizers were applied after 45 days from planting of the plants. Data were taken in May included plant height $(\mathrm{cm})$, number of branches, number of flowers, fresh and dry weight of plants (gm). The average temperature and rainfall during the growing time was measured "Table 1".

Tab.1. Mean monthly temperature $\left({ }^{\circ} \mathrm{C}\right)$ and rainfall $(\mathrm{mm})$ during the studying time

\begin{tabular}{|c|c|c|c|}
\hline \multirow{2}{*}{ Month } & \multicolumn{2}{|c|}{$\begin{array}{c}\text { Temperature in }{ }^{\circ} \mathrm{C} \\
\text { 2009-2010 }\end{array}$} & $\begin{array}{c}\text { Rainfall in } \mathbf{~ m m} \\
\mathbf{2 0 0 9 - 2 0 1 0}\end{array}$ \\
\cline { 2 - 4 } & minimum & maximum & 3.8 \\
\hline October & 15.2 & 21 & 1.3 \\
\hline Dovember & 10.5 & 18.5 & 3.5 \\
\hline January & 9 & 16.5 & 113.9 \\
\hline February & 5.4 & 12.4 & 42.8 \\
\hline March & 6.3 & 13.8 & 30.5 \\
\hline April & 9 & 18.9 & 101.5 \\
\hline May & 14.9 & 23.9 & 12.7 \\
\hline
\end{tabular}

\subsection{Plant height (cm)}

\section{Results And Discussion}

The plant height differed significantly due to nitrogen; significantly higher plant height $(35.000 \mathrm{~cm})$ was recorded with (N2) 1mg nitrogen / pot, "Fig. 1" [17] observed that plant height was enhanced by N fertilizer upto $100 \mathrm{~kg} \mathrm{~N} / \mathrm{ha}$. The plant height did not differ significantly due to phosphate additions, the plant height differ significantly due to interaction effect of phosphate and nitrogen level (P:0, N:0.5 mg/pot) "Table 2" The result agrees with [18] they observed significant increase in plant height $(47.9 \mathrm{~cm})$ in Chrysanthemum with the application of 300:400:200 kg NPK per ha. The result is compatible also with other research [19] that favorable conditions for plant growth in order to gain maximum quality require an adequate and balanced amount of nutrition elements in the soil. Similar results were also obtained by [20] who reported that NPK fertilizer significantly increased plant height. In calendula, application of (NPK) at the rate of (100:50:25 kg.ha-1) increased the height of plant, number of branches and leaves [21]. The highest height of plants found when used nitrogen (N1) without any phosphorus (P0), the value was $39 \mathrm{~cm}$ when comparing with $\mathrm{N} 0$, P0 which recorded $27 \mathrm{~cm}$ "Table 2". Adding phosphorus to soil low in available phosphorus promotes root growth and winter hardiness, stimulates tiller and often hastens maturity. Plants will typically be shorter or stunted and grow slower than plants with sufficient Nitrogen. Nitrogen stress also reduces the amount of protein in the seed and plant. Tiller can also be reduced in plants. 


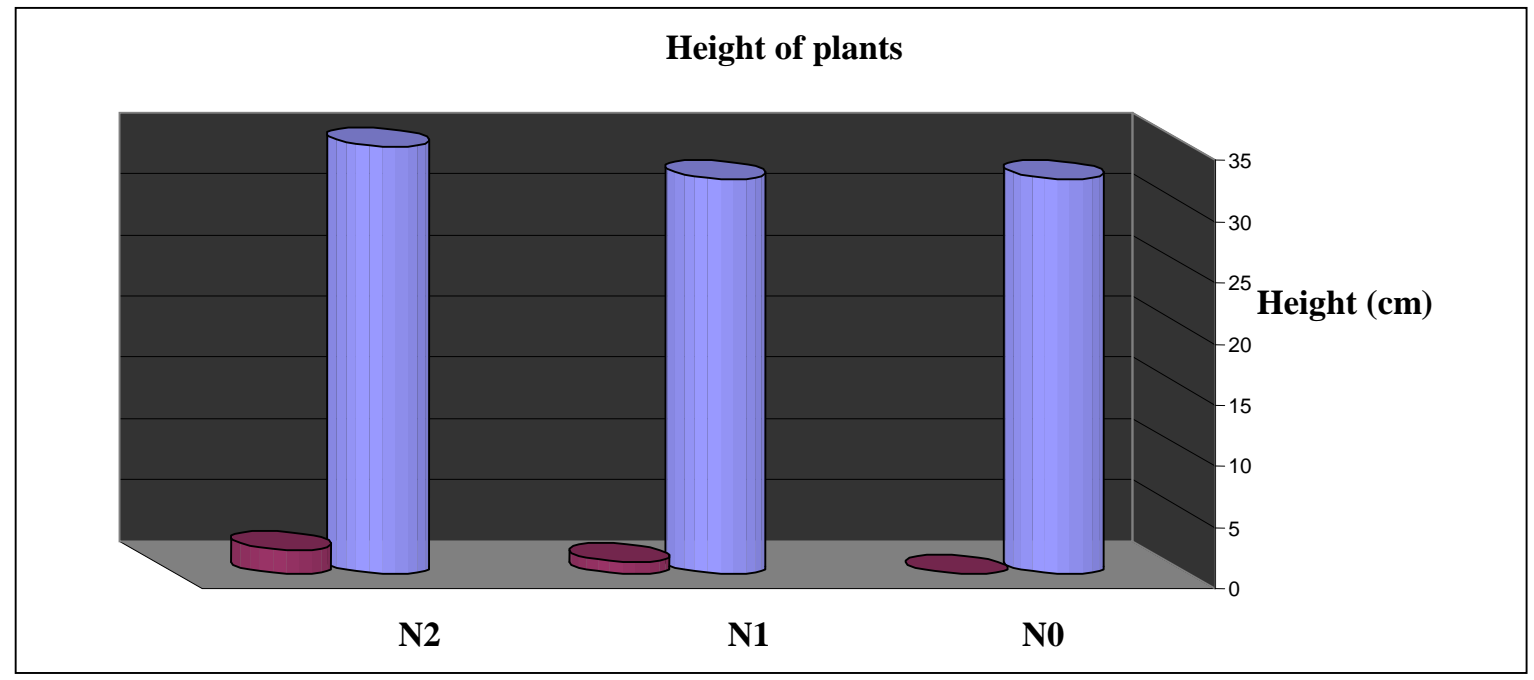

Fig.1. Effect of nitrogen on height of plants $(\mathrm{cm})$

Tab.2. Effect of nitrogen, phosphate and interaction between them on height of plants $(\mathrm{cm})$

\begin{tabular}{|c|c|c|c|c|c|}
\hline \multirow{2}{*}{\multicolumn{2}{|c|}{ height of plants }} & \multicolumn{3}{|c|}{ Factor N } & \multirow{3}{*}{$\begin{array}{l}\text { Mean P } \\
33.000 \text { a }\end{array}$} \\
\hline & & N0 & N1 & $\mathrm{N} 2$ & \\
\hline \multirow{3}{*}{ Factor P } & P0 & $27.000 \mathrm{~d}$ & $39.000 \mathrm{a}$ & $33.000 \mathrm{c}$ & \\
\hline & $\mathrm{P} 1$ & $33.000 \mathrm{c}$ & $29.333 d$ & $37.333 \mathrm{ab}$ & $33.222 \mathrm{a}$ \\
\hline & $\mathrm{P} 2$ & $37.000 \mathrm{ab}$ & $28.667 \mathrm{~d}$ & $34.667 b c$ & $33.444 \mathrm{a}$ \\
\hline \multirow{2}{*}{\multicolumn{2}{|c|}{ Mean N }} & $32.333 b$ & $32.333 b$ & $35.000 \mathrm{a}$ & \multirow{2}{*}{33.222} \\
\hline & & & & & \\
\hline
\end{tabular}

*Means not followed by the same letters are significant at 5\% level of probability

\subsection{Number of branches}

Number of branches did not affected by nitrogen and phosphate Fertilization, although the interaction between nitrogen and phosphate showed significant effect in (P0N0; P0N2 and P2N1) comparing with the other treatments "Table 3" The result disagreeing with [22] who obtained that the percentage of branched plants increased linearly with increased rate of $\mathrm{N}$ application thereby producing the maximum plants $(40 \%)$ under application of $120 \mathrm{~kg} / \mathrm{ha}$. Similarly,[23] noticed increased in the number of lateral branches per plant with the higher level of (nitrogen $200 \mathrm{~kg}$.ha-1) in Chrysanthemum coronarium. [24] studied the effect of nitrogen fertilization $(0,75$ and $150 \mathrm{~kg}$.ha-1 $\mathrm{N})$ on growth and flowering of Zinnia elegans plants, Nitrogen fertilization at $(150 \mathrm{~kg} / \mathrm{ha})$ caused a significantly increased in all vegetative growth, inflorescence characters when compared with the control. This result may be referring to nitrogen supply that increases the extra protein which allows the plant foliage to grow larger and hence increases its surface area available for photosynthesis.

Tab.3. Effect of nitrogen, phosphate and interaction between them on number of branches

\begin{tabular}{|c|c|c|c|c|c|}
\hline \multirow{2}{*}{\multicolumn{2}{|c|}{ Number of branches }} & \multicolumn{3}{|c|}{ Factor N } & \multirow{3}{*}{$\begin{array}{c}\text { Mean P } \\
7.444 a\end{array}$} \\
\hline & & No & N1 & N2 & \\
\hline \multirow{3}{*}{ Factor P } & $\mathrm{P} 0$ & $7.667 \mathrm{a}$ & 7.000ab & $7.667 \mathrm{a}$ & \\
\hline & P1 & $5.333 \mathrm{ab}$ & 5.667ab & 7.000ab & $6.000 \mathrm{a}$ \\
\hline & P2 & $4.333 \mathrm{~b}$ & $7.667 \mathrm{a}$ & 6.333ab & $6.111 \mathrm{a}$ \\
\hline \multirow{2}{*}{\multicolumn{2}{|c|}{ Mean N }} & $5.778 \mathrm{a}$ & $6.778 \mathrm{a}$ & $7.000 \mathrm{a}$ & \multirow{2}{*}{6.519} \\
\hline & & & & & \\
\hline
\end{tabular}

*Means not followed by the same letters are significant at 5\% level of probability 


\subsection{Number of flowers (spikes)}

Effect of nitrogen was significantly on number of flowers at N0 comparing with N1 "Fig. 2" .Nitrogen is a common plant nutrition which promotes vegetative developments in plants. The result is disagreeing with [25] reported that application of nitrogen at $300 \mathrm{~kg} / \mathrm{ha}$ followed by $250 \mathrm{~kg} / \mathrm{ha}$ number of flowers increased significantly in China aster. At the same direction may be refer to the same reasons which mentions in the previous characters which clarify by the positively correlated with plant length, branch number. We also know that high $\mathrm{N}$ promotes vegetative growth. Excessive $\mathrm{N}$ may produce vegetative growth at the expense of reproduction. While the addition of phosphorus increased the number of flowers "Fig.3" this agrees with [26] they observed that the number of fruit per plant increased with the increment of phosphorus of Capsicum significantly. Phosphorus is involved in flowering, fruiting, and seed production. It is used in plants to form part of an ATP compound used in most energy driven plant processes, such as nutrient uptake and photosynthesis. Interaction between nitrogen and phosphate significantly increased number of flowers at (N1P2), the value was (21.333) "Table 4" Nitrogen and phosphorus are essential elements for growth [27].

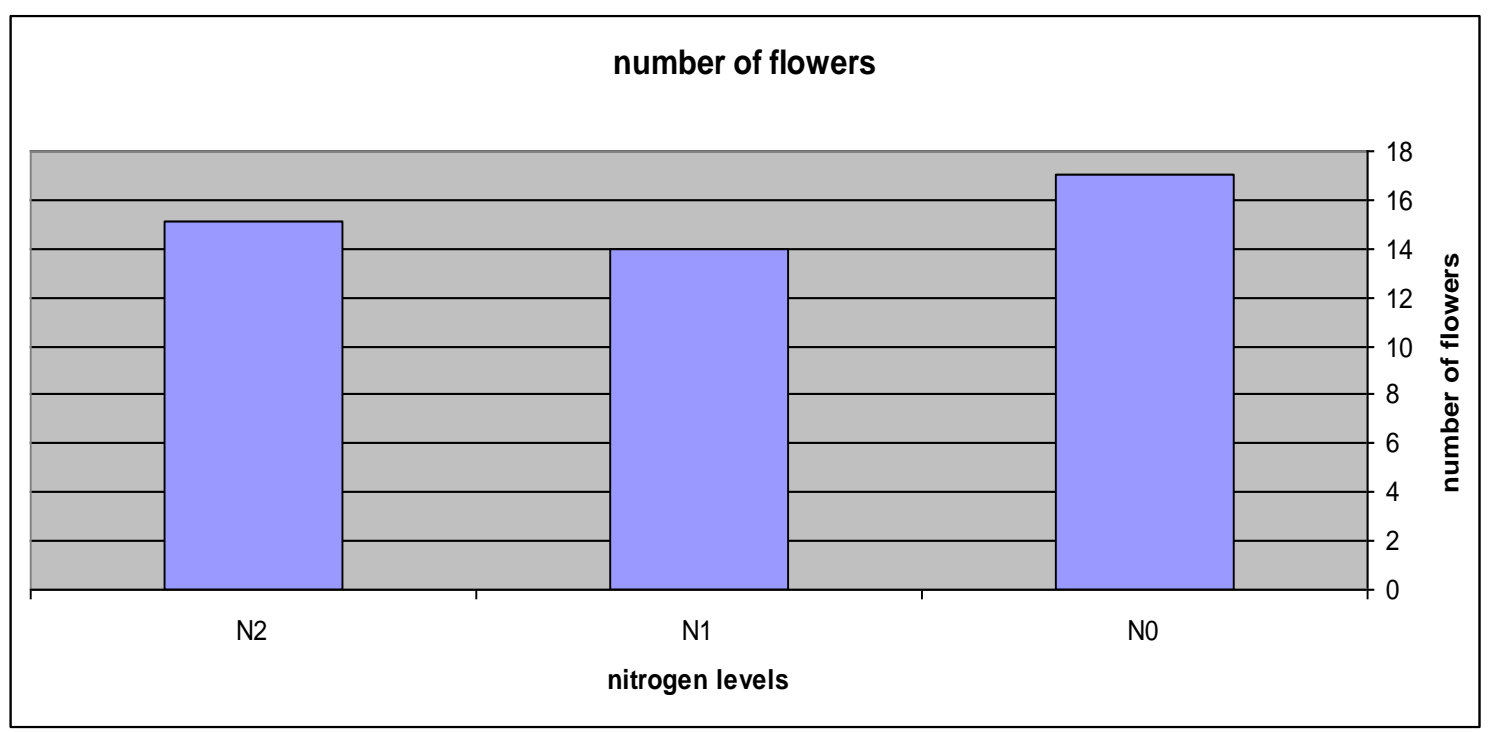

Fig.2. Effect of nitrogen on number of flowers

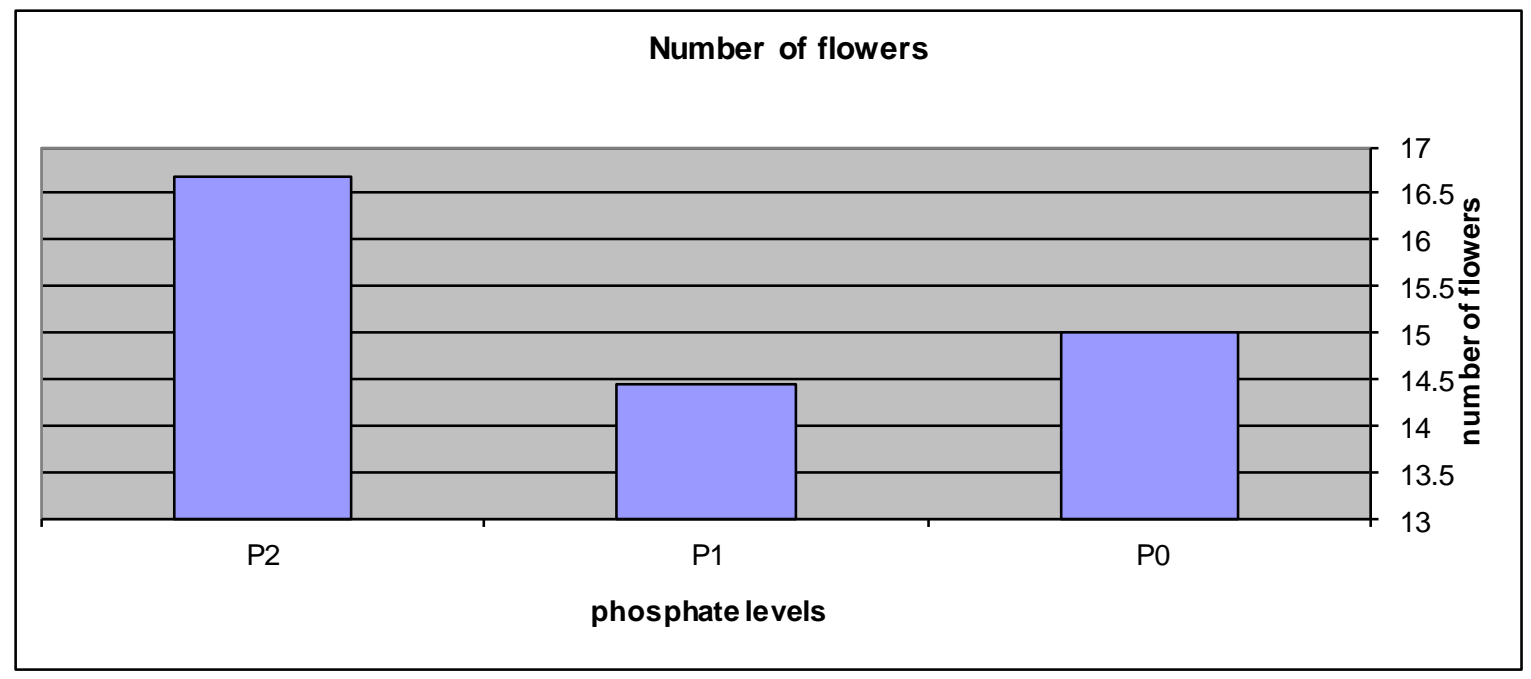

Fig.3 Effect of phosphate on number of flowers 
Tab.4. Effect of nitrogen, phosphate and interaction between them on number of flowers

\begin{tabular}{|c|c|c|c|c|c|}
\hline \multirow{2}{*}{\multicolumn{2}{|c|}{ Number of flowers }} & \multicolumn{3}{|c|}{ Factor $\mathrm{N}$} & \multirow{3}{*}{$\begin{array}{l}\text { Mean P } \\
15.000 \mathrm{ab}\end{array}$} \\
\hline & & N0 & N1 & $\mathrm{N} 2$ & \\
\hline \multirow{3}{*}{ Factor $\mathrm{P}$} & P0 & $19.333 a$ & $10.333 d$ & $15.333 b c$ & \\
\hline & P1 & $20.667 \mathrm{a}$ & $10.333 d$ & $12.333 \mathrm{~cd}$ & $14.444 \mathrm{~b}$ \\
\hline & $\mathrm{P} 2$ & $11.000 \mathrm{~d}$ & $21.333 \mathrm{a}$ & $17.667 \mathrm{ab}$ & $16.667 \mathrm{a}$ \\
\hline \multirow{2}{*}{\multicolumn{2}{|c|}{ Mean N }} & $17.000 \mathrm{a}$ & $14.000 \mathrm{~b}$ & $15.111 \mathrm{ab}$ & \multirow{2}{*}{15.370} \\
\hline & & & & & \\
\hline
\end{tabular}

*Means not followed by the same letters are significant at $5 \%$ level of probability

\subsection{Fresh and dry weight of plants (g)}

The wet (fresh) and dry weight of plants was significantly affected by nitrogen and phosphorus, the highest value recorded at N1 and P2 "Table 5, 6" This agree with [28]; [29] intensive agricultural production systems require strict and balanced fertilization management for generation of high yield of optimal quality. [30] explained that higher levels of nitrogen increased shoot vegetative growth and flower production and produced higher dry matter finally Many crops are heavy consumers of nutrients and can sustain high yields only through the application of optimal fertigation system; Nitrogen affects growth and morphological development[31]; [32]; [33]. In conclusion application of nitrogen fertilizer significantly improved heights of plants, number of branches, wet and dry weight of plants in strawflower. Phosphorus was obtained in treatment of number of flowers. Interaction between nitrogen and phosphorus lay to increase number of branches, number of flowers and wet and dry weight of plants. Nitrogen and phosphorus fertilizer significantly improve the quantity and quality characters compared to control. [34] Who found that nitrogen at $93.75 \mathrm{~kg}$ ha-1 gave the highest values fresh and dry weight of shoot, dry matter production in Artemisia pallens.

Tab.5. Effect of nitrogen, phosphate and interaction between them on plant wet weight

\begin{tabular}{|c|c|c|c|c|c|}
\hline \multirow{2}{*}{\multicolumn{2}{|c|}{ Plant wet weight }} & \multicolumn{3}{|c|}{ Factor N } & \multirow{3}{*}{$\begin{array}{l}\text { Mean P } \\
22.813 a\end{array}$} \\
\hline & & No & N1 & $\mathrm{N} 2$ & \\
\hline \multirow{3}{*}{ Factor P } & $\mathrm{P} 0$ & $20.230 \mathrm{ab}$ & $23.717 \mathrm{a}$ & $24.493 \mathrm{a}$ & \\
\hline & $\mathrm{P} 1$ & $13.387 b c$ & $20.947 a b$ & $16.767 b c$ & $17.033 b$ \\
\hline & $\mathrm{P} 2$ & $21.417 \mathrm{ab}$ & $23.613 a$ & $21.287 \mathrm{ab}$ & $22.106 \mathrm{a}$ \\
\hline \multirow{2}{*}{\multicolumn{2}{|c|}{ Mean N }} & $18.344 \mathrm{~b}$ & $22.759 a$ & 20.849ab & \multirow{2}{*}{20.651} \\
\hline & & & & & \\
\hline
\end{tabular}

*Means not followed by the same letters are significant at 5\% level of probability

Tab.6. Effect of nitrogen, phosphate and interaction between them on plant dry matter

\begin{tabular}{|c|c|c|c|c|c|}
\hline \multirow{2}{*}{\multicolumn{2}{|c|}{ Plant dry weight }} & \multicolumn{3}{|c|}{ Factor N } & \multirow{3}{*}{$\begin{array}{l}\text { Mean P } \\
7.122 \mathrm{a}\end{array}$} \\
\hline & & N0 & N1 & $\mathrm{N} 2$ & \\
\hline \multirow{3}{*}{ Factor P } & P0 & $6.973 \mathrm{ab}$ & $8.183 a$ & $6.210 \mathrm{ab}$ & \\
\hline & $\mathrm{P} 1$ & $4.580 \mathrm{~b}$ & $6.367 \mathrm{ab}$ & 6.070ab & $5.672 b$ \\
\hline & $\mathrm{P} 2$ & $8.310 \mathrm{a}$ & $7.823 \mathrm{a}$ & $5.827 \mathrm{ab}$ & $7.320 \mathrm{a}$ \\
\hline \multirow{2}{*}{\multicolumn{2}{|c|}{ Mean N }} & $6.621 \mathrm{ab}$ & $7.458 \mathrm{a}$ & $6.036 \mathrm{~b}$ & \multirow{2}{*}{6.705} \\
\hline & & & & & \\
\hline
\end{tabular}

*Means not followed by the same letters are significant at $5 \%$ level of probability 


\section{Conclusion}

Application of nitrogen fertilizer significantly improved height of plants, number of branches, wet and dry weight of plants in strawflower. Phosphorus was obtained in treatment of number of flowers. Interaction between nitrogen and phosphorus lay to increase number of branches, number of flowers and wet and dry weight of plants. Nitrogen and phosphorus fertilizer significantly improve the quantity and quality characters compared to control.

\section{References"}

[1] K.V. Sharman, M. Sedgley and D. Aspinall, Production of the Australian native daisies (Helichrysum roseum and Helichrysum bracteatum) for the cut flower market. Aust.J. Exper.Agric., 29, 1989a, 445-453.

[2] K.V. Sharman, M. Sedgley, and D. Aspinall, Effects of photoperiod, temperature and plant age in floral initiation and inflorescence quality in the Australian native daisies Helichrysum roseum and Helichrysum bracteatum in relation to cut flower production. J.Hort. Sci., 64, 1989 b, 351-359.

[3] K. Nishikawa, H. Ito, T. Awano, M. Hosokawa and S. Yazawa, Characteristic Thickened Cell Walls of the Bracts of the 'Eternal Flower' Helichrysum bracteatum". Annals of Botany 102 (1), 2008, 31-37.

[4] A. Sala, M.C. Recio, G.R. Schinella, S. Manez, R.M. Giner, and J.L. Rios, A new dual inhibitor of arachidonate metabolism isolated from Helichrysum italicum. European Journal of Pharmacology, 460, 2003, 219-226.

[5] G.R. Noggle, and J.G. Fritz, Introductory Plant Physiology. Prentice Hall of India Pvt. Ltd., New Delhi, 1979, 43-49.

[6] D. L. Maheshwar, Influence of nitrogen and phosphorus on growth and flower production in China aster (Callistephus chinensisi Nees). (Agri.) Thesis, Univ. Agril. Sci., Bangalore, Karnataka (India), 1997.

[7] C. Ramachandra, Studies on the effect of dates of planting with different levels of nitrogen and phosphorus on growth and flower production of China aster (Callistephus chinensis Nees.) cv. Ostrich Plume Mixed. M.Sc. (Agri) Thesis, Univ. Agril. Sci., Bangalore, Karnataka (India), 1982.

[8] A. R. Venkatesh, Effect of different levels of NPK on growth, yield and quality of China aster (Callistephus chinensis). M.Sc. (Agri) Thesis, Univ. Agril. Sci., Bangalore, Karnataka (India), 1983.

[9] S. M. Mantur, Studies on nutrition, growth regulators and soil salinity on flower and seed production in China aster. PhD Thesis, Univ. Agril. Sci., Dharwad, Karnataka (India), 1988

[10] B. N. Ravindra, Effect of nitrogen, phosphorus and potassium on growth, yield and quality of China aster (Callistephus chinensis Nees.) cv. Kamini. M.Sc. (Agri) Thesis, Univ. Agril. Sci., Dharwad, Karnataka (India), 1998.

[11] G. N. Dongre, Standardization of horticultural practices for commercial production of marigold (Tagetes erecta L.). M.Sc. (Agri.) Thesis, Univ. Agril. Sci., Bangalore, Karnataka (India), 1984.

[12] B.K. Jana, and A. Pal, Response of nitrogen and phosphorus on growth, flowering and seed yield of cosmos (Cosmos sulphureus) cv. Super Sunset. Indian Agri., 35, 1991, 113-118.

[13] S.A. Agrawal, N.A. Wal, and R. N. Yadav Effect of $\mathrm{N}$ and $\mathrm{K} 2 \mathrm{O}$ on African marigold in Chattisgarh region. Journal of Ornamental Horticulture, New Series, 5(10), 2002. 86

[14] B.N. Karavadia, and B.K. Dhaduk, Effect of spacing and nitrogen on annual chrysanthemum (Chrysanthemum coronarium) cv. Local white. J. Orn. Hort., New Series, 5(1), 2002, 65-66.

[15] C. R. Mohanty, N.K. Mishra, and P. Padmaja, Effect of nitrogen and phosphorus on flower production in marigold. J. Orn. Hort., New Series, 5(1), 2002, 67-68.

[16] M.M. Acharya, and L.K. Dashora, Response of graded levels of nitrogen and phosphorus on vegetative growth and flowering in African marigold. J. Orn. Hort., 7(2), 2004, 179-183

[17] I.S. Majanbu, V.B. Ogunlela, M.K. Abmed, and J.D. Olarewaju, Response of two okra varieties to fertilizers, yield and yield components as influenced by nitrogen and phosphorus application. Fertilizer Res. 6 (3), 1985, 257-267.

[18] R. Jayanthi, and J.N. Gowda, Effect of nitrogen and phosphorus on growth and flowering of Chrysanthemum, cv. Local White. Curr.Res, 17, 1988, 104-106.

[19] M.R. Khageh Poor, Doctrine and principles of farming. Publications University Jehad of Mashhad, 2007, 182-200.

[20] S.U. Gondane, and G.L. Bhatia, Response of okra genotypes to different enivorments. Punjabrao Krishi Vidyapeeth, Marashthra, India. PKV-Res. J., 19(2), 1995, 143-146.

[21] P. D. Sigedara. K. W. Adekar, and B. M. Rodge, Effect of different levels of NPK on growth and yield of Calendula officinalis Linn. South Indian Horticulture, 39, 1991, 308-311.

[22] Z.A. FIROZ, Impact of nitrogen and phosphorous on the growth and yield of Okra (Abelmoschus esculentus L). In hill slope condition. Bangladesh J. Agril. Res. 34(4), 2009, 713-722.

[23] D. V. R. Rao, S. A. Balasubramanyam, K. R. Balakrishna, and V. Suryanarayana Effect of different spacing and nitrogen levels on growth and flower yield of Chrysanthemum (Chrysanthemum indicum L.) cv. kasturi. South Indian Horticulture, 40(6), 1992,323 - 328.

[24] A. O. Al-Atrakchii, S. A. Qatar, and G. O. Al-Noaimy, Effect of Pinching and Nitrogen Fertilization on Growth and Flowering of Zinnia Plants Zinnia elegans Jacq. Mesoptemia J. Agric. 38(2), 2010.

[25] J. Khumar, S.S. Chauhan, and P.V. Singh, Response of N and P fertilization on China aster. Journal of Ornamental Horticulture, 6 (1), 2003,82 .

[26] M.S.I. Khan, S.S. ROY, and K.K. Pall, Nitrogen and phosphorus efficiency on the growth and yield attributes of Capsicum. Academic journal of plant Sciences 3 (2), 2010, 71-78.

[27] G.J. Banker, and A. Mukhopadhyay, Varital trial on tuberose (Polianthes tuberose L.) .Journal Indian Hort., 28 (4), 1980, 150-151.

[28] F. H. Abdullah, Effect of different levels of nitrogen, phosphorus and potassium on natural nodulat ions of broadband in land reclamation. Journal of Kofa for Agriculture Sciences, 2(1), 2010, 7-12.

[29] A. Ghaffoor, M. Shaheen, M. Iqbal, K. Waseem, and M.A. Nadeem, Impact of various combination of NPK on the growth, yield and quality parameters of Rose. Pakistan Journal of Biological Sciences 3 (10), 2000, 1560-1562.

[30] W. Letchamo, Nitrogen application affects yield and content of the active substances in chamomile genotypes. In: J. Janick and J.E. Simon (eds.), new crops. Wiley, New York, 1993, 636-639.

[31] P. Walch-Liu, G. Neumann, F. Bangerth, and C. Engels, Rapid effects of nitrogen form on leaf morphogenesis in tobacco. J. Exp. Bot. 51, 2000, 227-237.

[32] P. Walch-Liu, I.I. Ivanov, S. Filleur, Y.B. Gan, T. Re- mans, and B.G. Forde, Nitrogen regulation of root branching. Ann. Bot. London. 97, 2006, 875-881.

[33] M.L. Gifford, A. Dean, R.A. Guti errez, G. M. Coruzzi, and B.K. Irnbaum, Cell specific nitrogen responses mediate developmental plasticity. P. Natl. Acad. Sci. USA. 105, 2008, 803-808.

[34] T. Senthil Kumar, V. Swaminathan and S. Kumar, Influence of nitrogen, Phosphorus and Bio fertilizers on Growth, Yield and Essential Oil Constituents in Ratoons Crop of Davana (Artemisia Pallens Wall.). Electronic Journal of Environmental, Agricultural and Food Chemistry, $8(2), 2009,86-95$ 